Konrad Niciński

Instytut Kultury Polskiej Uniwersytet Warszawski

e-mail: knicinski@gmail.com

\title{
Fenomen „czerwoniaka” i legenda międzywojennej Warszawy
}

Czy tzw. prasę czerwoną, czyli sensacyjne dzienniki miejskie wydawane w latach 1921-1939 przez koncern Prasa Polska, godzi się nazwać warszawską legendą? To chyba pytanie otwarte, na które mogą paść bardzo różne odpowiedzi w zależności od kręgu odbiorców oraz przyjętej definicji pojęcia legendy ${ }^{1}$. Jeśli jednak sformułować je inaczej - czy można pisać o legendzie i międzywojennej Warszawie (w jakimkolwiek aspekcie) bez kontekstu „prasy czerwonej” ${ }^{2}$, to wydaje się, że odpowiedź musi być negatywna. Do podjęcia próby opisu legendy międzywojennej Warszawy - czym ona była i jest - powrót do "czerwoniaków” okazuje się konieczny choćby tylko ze względu na felietony Wiecha i ich wpływ na mit Warszawy plebejskiej.

1 Legenda należy do bodaj najmniej ostrych definicyjnie terminów wykorzystywanych przez antropologię kultury, o czym dobitnie świadczy jej nagminna nieobecność w stosownych słownikach i leksykonach. W niniejszym tekście rozpatrywane są aspekty związane $\mathrm{z}$ oralnym przekazem pamięci kulturowej, ale także z pojęciami legendy miejskiej i legendy literackiej (w tym wypadku - możliwości zaistnienia legendy nie twórcy, a czasopisma), przekraczającymi granice kultury oralnej i piśmiennej. Najbardziej kontrowersyjny, jak się zdaje, problem czy w dziedzinie studiów miejskich pojęcie legendy może przynależeć tylko do kultury oralnej i na ile uprawnione jest użycie tego terminu w związku z prasą "brukową" - pozostaje zagadnieniem otwartym, znacznie przekraczającym cele i ramy niniejszego szkicu.

2 Owo nom de guerre zawdzięczała ona kolorowi szpalt, nie zaś przekonaniom politycznym. Jak silnie zrosło się ono z pismem, uzmysławia fakt, że do 1925 r. nosiło ono nazwę "Kurier Informacyjny i Telegraficzny”. Nowa - „Kurier Czerwony”, czyniła oficjalną nazwą określenie potoczne, stosowane przez warszawiaków. 
A przecież na felietonach Wiecha wkład „prasy czerwonej” w kształtowanie się warstwy legendarnej, otaczającej międzywojenną Warszawę, ani się nie zaczyna, ani nie kończy.

Nie ulega wątpliwości walny udział „,czerwoniaków” w tworzeniu się legendy warszawskiego półświatka, a także w jej powojennej recepcji. W dużej mierze styl dzienników - relacjonowanie najgłośniejszych spraw kryminalnych na pierwszej stronie, troska o oprawę ilustracyjną, połączenie nadekspresyjnego stylu prasy rewolwerowej z dobrej klasy warsztatem literackim (zwłaszcza w zakresie kompozycji tekstu), umiejętna gra na emocjach czytelnika - tworzył monumentalny obraz przestępstw i przestępców, co prostą drogą prowadziło do przejścia słowa pisanego w mówione, tworzenia się legendy. Działo się tak tym bardziej, że ze względu na sugestywność opowieści i bogactwo szczegółów „czerwoniaki” stanowiły główne źródło informacji o przestępstwach dla wielu mieszkańców Warszawy, a więc podstawę relacji niesionych z ust do ust. Znamienne, że jeśli sylwetki przedwojennych warszawskich przestępców przywoływano - w coraz bardziej odrealnionym kształcie - po wojnie, to nieodmiennie byli to bohaterowie pierwszych stron "czerwoniaków" (jak Szpicbródka), względnie na ich łamach znaleziono nazwiska i ksywy pomocne w stworzeniu nowej narracji, ewokującej legendę na nowo (jak w obu częściach VaBank Juliusza Machulskiego ${ }^{3}$ ). Wydaje się także, że połączenie na łamach „prasy czerwonej” ogromnej liczby informacji o warszawskim środowisku przestępczym, traktowanym jako rodzaj grupy społecznej, ze środkami literackimi, takimi jak hiperbolizacja czy stylizacja na powieść tajemnic i charakterystyczny dla niej obraz „pracowników nocy", skutkowało trwałym wizerunkiem warszawskiego półświatka, cechującego się pewnym kanonem wewnętrznych reguł. Wizerunek ten okazał się po wojnie zaskakująco trwały i nabrał znamion legendy, choć jeśli przesadę i uwznioślenie uznać za jej cechy dystynktywne, to być może miał je od samego początku.

Naturalną konsekwencją funkcjonowania tego rodzaju pisma jest przyczynianie się do powstawania legend miejskich, zarówno wspomnianych już „wielkich narracji”, jak i legend mniej skodyfikowanych, za to głębiej może wnikających w życie codzienne. Jeśli w numerze „Expressu Porannego" z 1929 roku znajdujemy tytuł Poćwiartowane zwłoki porzucono w worku na Pelco-

3 Dotyczy to nie tylko personaliów postaci pierwszoplanowych, jak Kwinto czy Duńczyk. Jedną z milszych niespodzianek podczas pracy nad niniejszym tekstem było znalezienie na ostatniej stronie „Expressu Porannego" nazwiska komisarza Przygody. „Express Poranny” 23 stycznia 1930 r. donosił warszawiakom, że do stolicy przybył z Siedlec komisarz Leon Przygoda, mający objąć komendę nad komisariatem na Pradze. 
wiznie, to może być to tyleż pożywka, ile ugruntowanie rodzaju miejskiej legendy, a także związanego $z$ nią stereotypu przestrzennego. Nikt z nas nie zdziwiłby się, gdyby jutro znalazł identyczny tytuł na pierwszej stronie "Super Expressu". Skądinąd przykład ten świadczy dobitnie o nowoczesności przekazu „prasy czerwonej” i dość dobrze pokazuje, dlaczego to ona właśnie przejęła prymat wśród warszawskich pism popularnych od solidnych firm z długą tradycją, jak „Kurier Poranny”. Wydaje się też, że stosowane przez dziennikarzy „prasy czerwonej” strategie mogły, w dużej mierze świadomie, wpływać na tworzenie się miejskich narracji i legend, czego dokładniejszemu ukazaniu posłuży ostatnia część artykułu.

Dobór przykładów w niniejszym tekście ograniczony jest przede wszystkim do łamów „Expressu Porannego” w okresie 1928-1932. Konieczność tak drastycznego ograniczenia ram czasowych wynika z oczywistego ogromu materiału. Nie jest to jednak jedyny powód. Wybór pisma jest podyktowany wyraźnymi różnicami w charakterze wydawanych przez Prasę Polską dzienników ${ }^{4}$. Każdy ma dość wyraźnie określony charakter - dla nas najbardziej interesujący jest „Express Poranny”, zawierający najwięcej wiadomości miejskich, z ostatnią stroną, redagowaną przez Władysława Zambrzyckiego, będącą czymś pośrednim między kroniką wypadków, najczęściej sporządzaną na podstawie informacji policyjnych, a panopticum osobliwości miejskich. $\mathrm{Na}$ przedostatniej stronie znajdowały się informacje miejskie mniej sensacyjnej natury oraz reportaże sądowe, początkowo autorstwa Stanisława Ćwierczakiewicza, stopniowo przejmowane przez Wiecha, najczęściej z sądu okręgowego i dotyczące spraw poważnych, zabójstw i rabunków, niekoniecznie warszawskich. Najpoważniejsze przestępstwa trafiały na stronę pierwszą. „Kurier Czerwony" w drugiej połowie lat 20. skupia się na warstwie informacyjnej i społecznej; zawiera więcej wiadomości zagranicznych (także jego ostatnia strona poświęcona jest sensacjom i osobliwościom wziętym z prasy obcojęzycznej); wiadomości miejskie (wśród których sensacje stanowią niewielką część) i (ewentualnie) relacje sądowe usytuowane są na stronie ostatniej. Miasto bywa tam reprezentowane $\mathrm{w}$ reportażach, także $\mathrm{z}$ dzielnic plebejskich, często autorstwa Zambrzyckiego, a od 1930 r. coraz częściej Wiecha. Poranne „Dzień Dobry” stanowiło skrót „Expressu Porannego”, groszowy, a więc dla niewyrobionej publiczności. Co ciekawe, ostatnia strona nie jest powtórzeniem ostatniej strony „Expressu”, co pewnie byłoby prostsze i tańsze, a jej i strony przedostatniej uproszczoną i skróconą jeszcze parafrazą. „Dobry Wieczór", aspirujący do roli skrótu wszystkich pism, miał na tyle

\footnotetext{
4 Por. W. Władyka, Krew na pierwszej stronie, Warszawa 1982, s. 61-73; A. Paczkowski, Prasa codzienna Warszawy w latach 1918-1939, Warszawa 1983.
} 
niedookreślony charakter, że w 1932 roku zarzucono jego wydawanie. Pozostała po nim nazwa dołączona do "Kuriera Czerwonego".

Z kolei dobór ram czasowych wypływa z przekonania, że ów okres był zdecydowanie najbardziej owocny w dziejach tytułu. W 1928 r. "Express” jest już, w odróżnieniu od etapu sprzed 1926 roku, pismem w pełni dojrzałym, które $\mathrm{z}$ dość prymitywnego brukowca przeistoczyło się $\mathrm{w}$ dziennik łączący sensacyjność treści z wysoką jakością formy, umiejętnie docierający właściwie do wszystkich warstw społeczeństwa stolicy. Bodaj nigdy wcześniej i nigdy później dziennikarska kadra pisma nie była tak mocna. Krótko po 1926 roku do coraz bardziej profesjonalnego zespołu dołączyli doświadczeni dziennikarze tytułów konkurencyjnych, głównie „Kuriera Porannego" i „Kuriera Warszawskiego" (co po części wynikało z sukcesu finansowego koncernu, po części zaś ze wsparcia, jakiego Prasie Polskiej udzielał obóz sanacyjny). Większą jeszcze rolę odegrała rekrutacja współpracowników z niewielkim doświadczeniem, za to obdarzonych wyobraźnią, ułańską fantazją i, co niebagatelne, talentem literackim, którzy z warszawskiej codzienności potrafili wyłuskać cechy niezwykłe. Najgłośniejszym nazwiskiem (i jedynym, które per se należy do warszawskiej legendy) był tu oczywiście Wiech, jednak stał się on "lokomotywą" pisma już po 1932 roku. W omawianym okresie większą rolę odgrywali Stanisław Maria Saliński ${ }^{5}$, a zwłaszcza Władysław Zambrzycki, który redagował wtedy ostatnią stronę pisma, tę poświęconą wypadkom miejskim. W jego rękach, o czym pięknie świadczą wspomnienia Wiecha Piąte przez dziesiąte ${ }^{6}$, prosta kronika wypadków zamieniła się w kopalnię anegdot i jarmark niezwykłych zdarzeń, często śmiesznych, niekiedy przerażających"; często również fascynujących odmiennością kulturową, jak $\mathrm{w}-\mathrm{z}$ biegiem czasu zajmujących coraz więcej miejsca - opisach społeczności żydowskiej i cygańskiej. Na pewno też uroku ostatniej stronie dodawały dwie cechy dla Zambrzyckiego szczególne. Były to: upodobanie do curiosów, któremu jeszcze pełniejszy wyraz dał po wojnie na łamach „Expressu Wie-

5 Stanisław Maria Saliński w legendzie literackiej przetrwał uwieczniony przez Zbigniewa Uniłowskiego we Wspólnym pokoju jako niepoprawny opój z Kwadrygi, w środowisku pisarskim był rozpoznawalny, już po wojnie, głównie jako marynista.

6 S. Wiechecki (Wiech), Piate przez dziesiate, Warszawa 1970, s. 52-54.

7 Część tekstów z ostatniej strony „Expressu Porannego” z lat 1930-1931 podał do druku pod nazwiskiem Wiecha Robert Stiller (Skarby w spodniach, Kraków 2001), nie posiadając żadnych, poza intuicyjnymi, dowodów swej hipotezy. Argumenty na rzecz tezy o autorstwie Zambrzyckiego przedstawiłem już w artykule Długi cień Prusa nad Warszawa. Wiech, Zambrzycki, Tyrmand, ogłoszonym w tomie zbiorowym Realiści, realizm, realność (red. E. Paczoska i in., Warszawa 2013, s. 377-388) i pozwolę sobie ich w tym miejscu już nie powtarzać. Skądinąd jednym z koronnych argumentów jest wzmiankowane już świadectwo Wiecha - aż dziw, że Stiller o nim zapomniał. 
czornego", gdzie, znów na ostatniej stronie, prowadził przez lata kultową, jak można dziś powiedzieć, rubrykę, noszącą tytuł Kto chce, niech czyta (później Kto chce, niech wierzy), oraz rzadki talent do mistyfikacji, którego najbardziej pamiętnym świadectwem jest (przypisane Zambrzyckiemu przez Wiecha ${ }^{8}$ ) wymyślenie i skuteczne wprowadzenie do miejskiego krwioobiegu postaci hochsztaplera Cyniana. Zambrzycki odchodzi z pisma w roku 1932 i jest to koniec pewnej epoki.

Z pewnością ową aurę niezwykłości spraw pozornie banalnych próbował zachować Stefan Wiechecki, jednak ze względu na oczywiste różnice zainteresowań i stylu pisania znacznie bardziej skupiał się na jędrności anegdoty i jej warstwie dialogowej (na co wpływ mogły mieć jego wcześniejsze doświadczenia teatralne; nie przypadkiem $\mathrm{w}$ tekstach żydowskich Wiech jest bardzo bliski poetyce szmoncesu, w odróżnieniu od Zambrzyckiego), niż na niezwykłości zdarzeń i ich fabularyzacji. Wyraźny przełom nie wynika tylko ze straty jednego, nawet tak znakomitego, autora, ale i z przeciwnej, rzec można, tendencji, jaką jest rozrost kadry pisma i coraz większa rozpoznawalność jego najlepszych piór, co pośrednio skutkować będzie odejściem od stałego, codziennie powielanego układu kompozycyjnego na rzecz powtarzalności obowiązującej tylko danego dnia tygodnia (iżby wszystkich pomieścić). W ten sposób poważnie naruszony zostanie stały układ rubryk, na czym najbardziej ucierpi właśnie dział miejskich wypadków, który straci miejsce na ostatniej stronie pisma i ulegnie wyraźnej marginalizacji. Szczególną rolę w tej przemianie odegrał Wiech, przenosząc w 1933 roku punkt ciężkości działu reportażu sądowego z sądu okręgowego do grodzkiego, w którym czuł się znacznie lepiej. Sukces autorski Wiecha za jednym zamachem zmiótł na margines pisma "średni poziom" spraw sądowych (odtąd na łamach „Expressu” pojawiają się głównie sprawy najpoważniejsze i te, w których lubuje się Wiech, czyli najdrobniejsze) oraz miejską kronikę wypadków. Przeniesienie zainteresowania $\mathrm{z}$ wiadomości policyjnych na relacje $\mathrm{z}$ sądu grodzkiego zmieniło $\mathrm{w}$ zasadniczym stopniu także topografię miasta portretowanego przez "prasę czerwoną”. Tym dwóm obliczom topografii Warszawy, obecnym na łamach „Expressu”: z około 1930 roku, kształtowanemu przez sensacje relacjonowane na pierwszej i ostatniej stronie, i około 1935 - przez felietony sądowe Wiecha, warto przyjrzeć się uważnie, nie tylko dlatego, że określają one przemiany obrazu miasta w "prasie czerwonej”. Wydaje się, że może to być także trafne studium tego, jak zmieniały się sposoby postrzegania poszczególnych części miasta, co pozostało nie bez

8 S. Wiechecki, tamże. 
istotnego wpływu na kształt późniejszej legendy (lub legend) międzywojennej Warszawy.

Topografia Warszawy na łamach „Expressu” w okresie dominacji Zambrzyckiego ma dwa ośrodki. Pierwszym jest oczywiście Śródmieście, skupiające wszystkie nurty życia miasta, także życie wytworne, które Wiecha będzie interesowało w niewielkim stopniu. Za czasów Zambrzyckiego artykuły o fałszywym hrabim aresztowanym w apartamencie na ulicy Pięknej czy dramacie zazdrości na Marszałkowskiej będą magnesem przyciągającym zwłaszcza czytelników z bardziej peryferyjnych dzielnic. Agorą miasta, i to bez względu na stan społeczny, pozostaje Krakowskie Przedmieście, z dziennym życiem kawiarnianym oraz wieczorno-nocnym chórem szoferów i rzezimieszków, pojadających kiełbaski nad kołłem u Fuksa, żebraków kręcących się przy pomniku Mickiewicza i pod kościołami czy, ściganych przez posterunkowych, pijaczków, najczęściej próbujących zaspokoić potrzeby gardła pod pomnikiem Wdzięczności Ameryce ${ }^{9}$. Wiech właściwie przejmie ten obraz stworzony przez Zambrzyckiego, z wyjątkiem oczywiście nieistniejącego już wtedy pomnika Wdzięczności, którego funkcję przejmie otwarty w lutym 1930 roku bar Pod Pomnikiem (którego inauguracji „Express Poranny” poświęcił spory artykuł ${ }^{10}$ ). Drugim ważnym ośrodkiem jest dzielnica żydowska, wobec której Wiech będzie używał stałego eufemizmu „północna dzielnica naszego miasta", pięknie podkreślającego jej odrębność. Zambrzycki, zafascynowany wszelkiego rodzaju odrębnościami kulturowymi, w mniejszym stopniu tropił drobne przestępstwa, w większym zaś osobliwości - z punktu widzenia chrześcijańskich mieszkańców miasta - życia religijnego, w tym sfer chasydzkich, pochówków, świąt, sądów rozjemczych. Bogactwo przekazywanych przezeń informacji wyraźnie wskazuje na dobre kontakty w postępowych kręgach rabinackich. Wiech po części przejmie tę narrację dzielnicy północnej jako krainy czarów, często kojarzonej w związku z tym z purnonsensowym humorem, aczkolwiek ,jego" dzielnica będzie uboższa, a jej atrakcyjność ograniczona w zasadzie do utarczek miłosnych i finansowych, które znajdowały finał w sądzie grodzkim.

Z kolei $\mathrm{w}$ topografii Wiecha pocześniejsze miejsce niż u Zambrzyckiego zajmie Wola. Na mapie tego drugiego jest ona dzielnicą tyleż interesującą, ze względu na bogate życie plebejskie i coraz liczniej zamieszkujących te okolice „poważnych" rzezimieszków (owa uchwytna na łamach „prasy czerwonej” migracja, najczęściej z Powiśla i Śródmieścia, znajdzie pełniejszy obraz u Wie-

9 Szczególnie uroczym świadectwem jest notatka z 24 maja 1930 r. o rozpaczliwej próbie obronienia pomnika przez grono stałych konsumentów.

10 Numer z 22 lutego 1930 r. 
cha), co niedookreśloną. W zasadzie główną wizytówką Woli Zambrzyckiego jest Cyrk przy Dzikiej i jego barwni mieszkańcy ${ }^{11}$. Wiech nie straci oczywiście cyrkowców z pola widzenia, przeniesie jednak oś narracji na życie plebejskie, a jego ośrodkiem uczyni plac Kercelego. Praga u Zambrzyckiego występuje głównie przy okazji wątków żydowskich; najbardziej prawdopodobną przyczyną takiego stanu rzeczy mogła być słaba znajomość dzielnicy, a także, co skądinąd szło w parze, luźne kontakty z tamtejszymi komisariatami. Jeśli około 1930 roku praski brzeg jest często obecny na łamach pisma, to albo jako miejsce najzupełniej dzikie (patrz przywołany wyżej przykład Pelcowizny), albo przy okazji regularnie powracającego w latach 1929-1931 na ostatniej stronie i dość wcześnie kształtowanego niczym zwarta narracyjnie całość wątku terroryzującej praską gminę żydowską radykalnej sekty, określanej jako czciciele rudej krowy, czyli narracji również stanowiącej pewną skrajność, jeśli idzie o ukazywanie dziwaczności obyczajów żydowskiej Warszawy. Wiech poświęci Pradze dużo więcej miejsca; w jego opowieści prawy brzeg, zwłaszcza północne rubieże, stanie się rodzajem plebejskiego miasteczka przy mieście, gdzie ,jest także samo drapacz chmur, tyle że drewniany", między domami biegają króliki, a rozrywkę stanowi siedzenie przed domem i patrzenie przed siebie („u nasz na Targówku to przyjęte”). Nieprzypadkowo akcję części reportaży ukazujących warszawskie zwyczaje (Herody, święcone) Wiech umieszcza na Nowym Bródnie, tam też, początkowo wymiennie z Targówkiem, lokuje rodzinne pielesze wymyślonego przez siebie archetypalnego warszawskiego plebejusza, pana Teosia Piecyka (który zresztą początkowo na zmianę jest Teodorem lub Teofilem). Można rzec, że jeśli pasja etnologiczna Zambrzyckiego znajduje ujście w podpatrywaniu dziwnych obyczajów żydowskich i cygańskich, to Wiech, mniej wyczulony na metafizykę i kulturę duchową, bardziej na swojskość i anegdotę, skupi swoją uwagę na chrześcijańskim ludku Woli i Pragi, sobie też najlepiej znanym. Stare Miasto w topografii Zambrzyckiego gra rolę niewielką; jest to dzielnica biedoty i drobnych rzezimieszków, najczęściej pojawiająca się jako miejsce zamieszkania panien lekkich obyczajów. Wiech poświęci Starówce wiele uwagi dopiero w Cafe pod Minogą, co po części wynika z tego, że jej mieszkańcy rzadko spotykali się w sądzie. I tu znajduje się chyba jeden z kluczy do zmian

11 Tzw. Cyrk przy Dzikiej 62 był schroniskiem dla najuboższych, prowadzonym od $1885 \mathrm{r}$. przez braci albertynów i stanowił w międzywojennej Warszawie synonim najdalszego skraju marginesu społecznego. Nie bez powodu. O licznych awanturach i przestępstwach tzw. cyrkowców nad wyraz często informowała „prasa czerwona”, a dość dobitnym potwierdzeniem złej sławy Cyrku był fakt, że schronisko albertynów na praskim brzegu, przy ul. Jagiellońskiej, bezdomni określali jako „Cyrk dla inteligencji”. 
topografii stolicy po 1932 roku - we wspomnianym już przeniesieniu środka ciężkości z kroniki wypadków na wiadomości z sądu grodzkiego.

Siłą rzeczy w topografii Wiecha słabiej uobecni się Powiśle, którego mieszkańcy pojawiać się będą głównie jako oskarżeni o przestępstwa popełnione $\mathrm{w}$ innych częściach miasta, a niemal zupełnie niewidoczne będą Czerniaków i okolice Powązek - ich mieszkańcy zarówno sprawy nieprawnego zarobku, jak i wymierzania sprawiedliwości załatwiali raczej we własnym kręgu, w sądzie zatem gościli niezmiernie rzadko. Zmienia się także sposób opisywania Ochoty, Mokotowa i Bielan z Marymontem. W wersji Zambrzyckiego są to okolice półdzikie, wiejskie raczej niż miejskie. $W$ opowieściach dotyczących Ochoty dominuje specyfika rogatki miejskiej - rabunki na przybywających $z$ towarem rolnikach czy ich brewerie w knajpach na Grójeckiej. Wbrew późniejszym stereotypom to $\mathrm{w}$ opisie Ochoty, a nie Woli, najwyraziściej ujawnia się stylistyka Dzikiego Zachodu. Mokotów w wydaniu Zambrzyckiego żywo przypomina Chełm w narracji żydowskiej. Na ostatniej stronie Mokotów regularnie powraca w anegdotycznych notatkach, w których jest przedstawiony wciąż bardziej jako wieś niż część miasta, w dodatku stanowiąca ostoję głupoty, prymitywizmu, a czasem i zabobonu (wątek sekty Badaczy Pisma powiązany przestrzennie z ulicą Puławską ${ }^{12}$ ).

Z kolei północne rubieże miasta pojawiają się przed 1932 rokiem przede wszystkim ze względu na Marymont, ukazywany jako królestwo Cyganów, niezmiernie fascynujących Zambrzyckiego, bardzo rzadko obecnych na kartach pisma za dominacji Wiecha. Rosnąca fascynacja Zambrzyckiego społecznością cygańską znalazła kulminację latem 1930 roku w serii obszernych not i reportaży ${ }^{13}$, także umieszczonych $\mathrm{w}$ środkowej części pisma, skupionych wokół prób detronizacji króla Cyganów, Bazylego Kwieka (rozpoczętych elekcją, przegraną na rzecz Michała Kwieka w styczniu tego roku ${ }^{14}$ ) oraz próbujących szerzej ukazywać także romską obyczajowość i wierzenia. $\mathrm{W}$ latach 30. wszystkie te dzielnice stopniowo znikają z kronik wypadków. Wyraźnie zaznacza się migracja do świeżo wybudowanych kamienic i pierwszych bloków inteligencji oraz tzw. arystokracji robotniczej. Dominującą narracją $w$ opisie wszystkich dzielnic staje się rozbudowa Wielkiej Warszawy (w przypadku Mokotowa zapewne owa zmiana narracji wiązała się również z unikaniem sądów przez rdzennych mieszkańców).

12 M.in. dość obszerny tekst w numerze z 9 kwietnia $1930 \mathrm{r}$.

13 M.in. w numerach z 3 lipca, 1 i 3 sierpnia. Ten ostatni zawiera obszerny reportaż podpisany przez Zambrzyckiego (co do 1932 r. było w pismach Prasy Polskiej rzadką praktyką, ów zwyczaj do dziś poważnie utrudnia atrybucję tekstów).

14 Numery z 27 i 28 stycznia 1930 r. 
Od tak poprowadzonej stabilnej narracji, kształtującej stereotypowe obrazy poszczególnych dzielnic, do legendy miejskiej jest już bardzo niedaleko. Zakres skuteczności i różnic między świadomie kreowanym obrazem a nie $\mathrm{w}$ pełni świadomym działaniem, opartym na cechującej stereotyp repetycji, jest tu jednak płynny. Możemy słusznie doszukać się w powtarzających się, także jako opowieść zasłyszana, na łamach „Expressu Porannego" wizerunkach nocnych stróżów, zarąbujących swoją żonę i dzieci siekierą lub duszących je poduszką, cech legendy miejskiej, ale jest to raczej sugestywność stereotypu niż celowe budowanie zmitologizowanej narracji. Niemniej jednak być może te właśnie stereotypowe obrazy okazywały się najskuteczniejsze. Na pewno istotnym składnikiem tak pojętych działań były charakterystyczne dla prasy rewolwerowej tytuły, emocjonalne, sugestywne i oparte na oczywistości oraz powtarzalności skojarzeń.

Proces kształtowania się legendy miejskiej na łamach „prasy czerwonej” dobrze obrazują trzy przypadki, w których świadome konstruowanie narracji zderza się $\mathrm{z}$ równie sugestywnymi elementami przypadkowymi, wynikającymi $\mathrm{w}$ pewnej mierze $\mathrm{z}$ dziennikarskiej rutyny, podstawowym zaś budulcem legendy pozostaje jednak naturalny bieg zdarzeń. Dwa pierwsze to głośne sprawy kryminalne, relacjonowane na pierwszych stronach dziennika. W końcu października 1928 roku Warszawą wstrząsnął brutalny mord na ulicy Foksal. Podczas napadu rabunkowego została tam uduszona służąca właściciela mieszkania, niejaka Franciszka Anczewska. Jak ujawniono w toku relacjonowanego śledztwa, wykorzystano jej słabość do mężczyzn - członkiem szajki był podstawiony Anczewskiej przez bandytów kolejny narzeczony. "Mózgiem” napadu okazał się Hipolit Rytter, należący do warszawskiej legendy miejskiej jeszcze na długo przed owym zdarzeniem, znany pod pseudonimem Hipek-Wariat. Przebieg relacji dość dobrze ukazuje złożony proces narastania legendy ${ }^{15}$. $\mathrm{Z}$ jednej strony widoczny jest cały szereg środków użytych celowo: drobiazgowy opis połączony ze stałymi epitetami i powtarzalnymi chwytami retorycznymi; budowanie napięcia między poszczególnymi relacjami; niedopowiadanie szczegółów, także wtedy, gdy są one znane, ale mogą posłużyć bardziej precyzyjnej narracji w kolejnym numerze; powtarzanie $\mathrm{w}$ detalach przebiegu zbrodni. $\mathrm{Z}$ drugiej strony równie skuteczną pożywką legendy miejskiej wydaje się chaos relacji w pierwszych dwóch dniach, wynikający po części z naturalnego biegu wypadków (szoku świadków, niepewności dziennikarzy co do tego, kto jest wiarygodnym źródłem informacji), po części zaś $\mathrm{z}$ rutynowego bogactwa opisu, mającego

15 Sprawa ta stała w centrum zainteresowania pisma od 24 listopada (pierwsza relacja z miejsca zbrodni) do 2 grudnia $1928 \mathrm{r}$. 
sprawiać wrażenie możliwie szczegółowego sprawozdania (także wtedy, gdy pewne detale w rzeczywistości celowo zachowane zostały na później). Akurat w przypadku zabójstwa przy ul. Foksal doszło do dość rzadko zdarzającej się profesjonalistom z "czerwoniaka" wpadki, mianowicie w pierwszej relacji błędnie podano nazwisko ofiary. Także $\mathrm{w}$ ogólnym opisie przebiegu zbrodni w kolejnych dniach pojawiły się znaczące zmiany, co wynikało zapewne $\mathrm{z}$ głębokiego szoku, $\mathrm{w}$ jakim bezpośrednio po zabójstwie znajdowała się dwójka bezpośrednich świadków.

Wydaje się, że ten nieintencjonalnie stworzony szum informacyjny mógł skutecznie „napędzać” legendę miejską. Z pewnością tak się zdarzyło w przypadku sensacji pierwszych miesięcy 1930 roku, czyli napadu na bank w Częstochowie ${ }^{16}$, którego „mózgiem” w relacji „Expressu” rychło okazał się Szpicbródka, czyli Stanisław Cichocki, kasiarz, podobnie jak Hipek-Wariat, już na długo przed napadem cieszący się bogatą legendą. Tutaj śledztwo początkowo przebiegało dość opornie, co w oczywisty sposób potęgowało szum informacyjny; kolejną naturalną komplikacją było oddalone od Warszawy miejsce przestępstwa. Dopiero wiosną reporterzy „Expressu” mogli, znając już ustalony przebieg zdarzeń, budować świadomie legendotwórczą narrację, której ośrodkiem była oczywiście już istniejąca legenda arcyprzebiegłego „króla kasiarzy”. Wydaje się jednak, że największą siłę kreowanemu wówczas aspektowi mitu nadał kolejny przypadek od redakcji niezależny - ucieczka Cichockiego $\mathrm{z}$ więzienia ${ }^{17}$, potwierdzająca tworzony właśnie legendarny rys "nieuchwytnego". Trzecim przykładem, o tyle innym, że dotyczącym miejsca, a nie zbrodni, i zdarzeń opisywanych na ostatniej stronie dziennika, nie zaś spektakularnych przestępstw ze strony pierwszej, jest wspominana już narracja skupiona wokół Cyrku przy ul. Dzikiej. Tu również pożywką legendy był w dużej mierze naturalny bieg wypadków, trudno bowiem oczekiwać, by zamieszkujący noclegownię kwiat warszawskiego marginesu społecznego nie przynosił regularnie tematów kronice kryminalnej. Różnica polegała na strategii operowania materiałem, w o wiele większej mierze pozbawionej elementów przypadkowych niż w dwóch wcześniejszych przykładach. I znów odmienność zasadza się na charakterze obu tematów. W dwóch pierwszych sytuacjach reporterzy opisywali wypadki „na gorąco", co w oczywisty sposób ograniczało możliwości komponowania narracji. Tutaj i możliwość dokładnego rozpoznania przedstawianego środowiska, i znacznie mniejszy kaliber przestępstw, zostawiający większe pole do popisu sztuce narracji, szły w sukurs narratorowi. Trzeba tu jednak podkreślić jego udział - reporter

\footnotetext{
16 Numer z 28 stycznia $1930 \mathrm{r}$.

17 Numer z 8 października 1930 r.
} 
z wykroczeń cyrkowców umiał uczynić przyciągającą uwagę, spójną opowieść. Udało się utrafić w lekki, humorystyczny ton, ukazać wręcz kuglarstwo widoczne w podstępach cyrkowców (dobrze uchwycona gra znaczeń epitetu), a równocześnie zachować werystyczny obraz skrajnej nędzy; w osiągnięciu tego efektu pomogły też celne portrety "stałych podejrzanych" (ulubioną postacią Zambrzyckiego był bodaj były rotmistrz lejbgwardii carskiej Konstanty Demidow, znany także jako Kostek Kacap).

Opowieść o cyrkowcach jest przypadkiem granicznym między narracjami tworzonymi w dużej mierze przez życie, a tymi, które w całości lub części zawdzięczały swoje powodzenie talentom fabularyzacyjnym, a niekiedy wręcz konfabulacyjnym, dziennikarzy. Wśród tych ostatnich zdecydowanie największą skutecznością, jeśli mowa o zaistnieniu wśród legend miejskich, cieszyły się opowieści o duchach i zjawiskach nadprzyrodzonych. Nie była to oczywiście w Warszawie rzecz nowa. W spirytyzmie specjalizował się już „Kurier Poranny” dobre dwie dekady przed końcem XIX wieku. „Prasa czerwona” zatem udatnie podchwyciła narrację liczącą sobie w warszawskiej prasie popularnej już niemal pół wieku. Szczególnie łaskawym dla historii o duchach rokiem był 1928. Na początku października zmarł Jan Guzik, medium cieszące się na początku wieku europejską renomą, później, po zdemaskowanym oszustwie, pogrążony w niesławie. Po śmierci Guzika „Express Poranny” podjął próbę przywrócenia blasku jego legendzie ${ }^{18}$.

Pod koniec tego samego miesiąca "czerwoniaki” szybko i z powodzeniem zbudowały legendę miejską wokół samobójczej śmierci barytona opery warszawskiej, Adama Ostrowskiego, którego duch tuż po zgonie miał pojawić się $\mathrm{w}$ Teatrze Wielkim. Po kilkudniowym serialu $\mathrm{z}$ widmem śpiewaka w roli głównej ${ }^{19}$ gazeta postawiła kropkę nad i także w rozpoczętej wcześniej fabule, relacjonując ukazanie się podczas seansu spirytystycznego widma zmarłego medium ${ }^{20}$. Kolejne lata nie notowały już tak spektakularnych wypadków w sferze pozazmysłowej, „prasa czerwona” jednak skutecznie kreowała mody w świecie mediów, np. aktywnie współtworząc legendę Stefana Ossowieckiego ${ }^{21}$, innych zaś bezlitośnie dyskredytując. Szczególnie ulubionym obiektem drwin był wróż z dzielnicy północnej, Szyller-Szkolnik, którego złote myśli wykorzystywano regularnie jako kontrapunkt do równolegle prowadzonych narracji o Guziku i Ostrowskim.

\footnotetext{
18 Numer z 7 października $1928 \mathrm{r}$.

19 26-29 października $1928 \mathrm{r}$.

20 Numer z 4 grudnia 1928 r.

21 Patrz numer z 15 sierpnia $1930 \mathrm{r}$.
} 
Kolejną legendą opartą przede wszystkim na talentach fabularyzacyjnych twórców "prasy czerwonej”, acz cieszącą się tym statusem głównie w wąskim środowisku varsavianistów, jest mit hochsztaplera Jana Cyniana, według Wiecha - genialna mistyfikacja wykreowana przez Władysława Zambrzyckiego. Czy tak było $\mathrm{w}$ istocie, nie wiadomo. Kilkanaście lat temu Stanisław Milewski, znany varsavianista specjalizujący się $\mathrm{w}$ dziejach stołecznej przestępczości, podważył hipotezę o nieautentyczności postaci Cyniana, powołując się na relację z jego procesu, znalezioną na łamach „Polski Zbrojnej" 22. Czy Cynian rzeczywiście był tylko tworem wyobraźni Zambrzyckiego? Wiele wskazuje na to, że nie. Jedyny większy tekst o Cynianie na łamach „Ekspressu Porannego" dotyczy sprawy oszukańczego rozebrania i spieniężenia torów tramwajowych na Burakowie ${ }^{23}$, czyli tej samej, o której pisze Milewski. Wcześniejsza wzmianka w „Kurierze Czerwonym" o sprzedaniu przez Cyniana kmiotkowi spod Radomia Kolumny Zygmunta, co odnotowuje również Zambrzycki we wspomnianym artykule, sprawia wrażenie przygotowania do publikacji w „Expressie”. Wspominanej $\mathrm{w}$ tym samym tekście sprawy sprzedaży naiwnemu tramwaju $\mathrm{z}$ remizy na Muranowie nie udało się znaleźć $w$ innych źródłach. Zgodnie z tym, co podaje Milewski, i w publikacji w „Expressie” Cynian nosi imię Alfons (a nie Jan, jak chce Wiech); co więcej, w kolejnym numerze zostało opublikowane jego zdjęcie. Nie można jednak całkowicie wykluczyć tego, że Cynian był genialną blagą Zambrzyckiego, tyle że o bardziej jednorazowym charakterze, niż chciał Wiech. Brak innych tekstów nie potwierdza $\mathrm{w}$ gruncie rzeczy żadnej $\mathrm{z}$ tez. Fotografia Cyniana mogła stanowić część mistyfikacji. Niewykluczone, że był nią także - nieintencjonalnie - materiał zamieszczony w „Polsce Zbrojnej”, który autorom mogli podesłać koledzy $\mathrm{z}$ „Expressu”. Wiech mógł mylić się co do Cyniana, miał jednak rację, jeśli mowa o uprawianiu przez Zambrzyckiego podobnych praktyk. Na ostatniej stronie „Expressu” pojawia się bowiem kilka postaci, które być może odpowiadają osobom rzeczywistym, ale część poświęconych im tekstów sprawia wrażenie silnie fabularyzowanych (skądinąd podobnie z prawdy i fikcji mógł zostać ulepiony Cynian). Dobry przykład stanowi inny hochsztapler, tym razem z dzielnicy północnej, rzekomy uzdrowiciel reb Kałmen Gajer. Wydaje się jednak, że najpiękniejsza kreacja legendy osobistej, której udało się dokonać Zambrzyckiemu, dotyczy postaci jak najbardziej autentycznej, rabina-rozjemcy reb Symchy Dona. Reb Don pierwszy raz pojawił się na ostatniej stronie „Expressu Porannego" w maju 1929 roku i po-

22 S. Milewski, Szemrane towarzystwo niegdysiejszej Warszawy, Warszawa 2009.

23 Numer z 8 marca $1930 \mathrm{r}$. 
został na niej aż do końca współpracy Zambrzyckiego z pismem; w latach 1930 i 1931 opowieści o nim zamieszczano na łamach „Expressu” co najmniej dwa razy w miesiącu. Można przypuszczać, że Zambrzycki, tworząc obraz sprawiedliwego rozjemcy, którego mądrość i łagodny dowcip opromienia północną dzielnicę naszego miasta, dokonał pastiszu poetyki opowieści chasydzkiej, jest to jednak pastisz dobrotliwy, nigdy szyderczy, a chyba też i dobrze służący sprawie ukazania duchowości i obyczaju owieczek reb Dona warszawskim chrześcijanom. Najpiękniejsze spośród historii o reb Donie, jak tę o salomonowym wyroku rebego, egzekwującym odzyskanie kozy z rąk przywłaszczyciela, który, powołując się na Talmud, nie chciał oddać jej prawowitym właścicielom póki nie nakaże mu tego prorok Eliasz ${ }^{24}$, w całości utrzymaną w poetyce świadectwa pobożnego Żyda, z pewnością zaliczyć należy do największych osiągnięć literackich Zambrzyckiego.

Czy tzw. prasę czerwoną, czyli sensacyjne dzienniki miejskie wydane w latach 1921-1939 przez koncern Prasa Polska, godzi się nazwać warszawską legendą? Współczesna recepcja wskazywałaby na to, że raczej nie. Jeśli nawet były one nośnikiem przekazów w jakimś stopniu żywych do dziś, to jako nazwa czy pojęcie nie przetrwały w powszechnej świadomości warszawiaków; co najwyżej w świadomości varsavianistów, a to ogromna różnica. Wydaje się jednak, że pod dwoma względami powojenna recepcja "prasy czerwonej" nosi pewne cechy legendy. Pierwszy aspekt to związanie pamięci o "czerwoniakach" z nazwą/nazwami potocznymi i jakimś ogólnym ich wyobrażeniem. Ilekroć pamięć ta wracała, czy to za sprawą kolejnych nawrotów mody na warszawski folklor miejski, czy to przy okazji mody na retro w latach 70. i na początku 80. oraz kolejnych premier filmowych (Hallo Szpicbródka, VaBank), czy wreszcie w kontekstach literackich (twórczość Wiecha, a w kręgu odbioru literatury wysokiej - odkrycie w latach 70. Opętanych Gombrowicza), tylekroć pojawiała się ona jako zbiór skojarzeń (folklor miejski, prasa rewolwerowa), najczęściej niepoparty znajomością dziennika. Innymi słowy, funkcjonowała jako zasób pamięci, ciąg reminiscencji, nie jako coś, co zostało przeczytane i poznane. Po drugie, uważny czytelnik być może odnotował, że niniejszy tekst pozbawiony jest odniesień historyczno-politycznych, co mógł uznać za oczywistość, jako że recepcja „prasy czerwonej” obywa się bez nich. Szkopuł jednak w tym, że ów wizerunek popularnego dziennika skupionego na sensacjach i życiu miasta w jakimś sensie też jest legendą. Jeśli bowiem podjąć próbę przygotowania

24 Przedruk w: R. Stiller, Skarby w spodniach, s. 115-116. 
rzetelnej monografii koncernu Prasa Polska, to kontekst polityczny okaże się wyjątkowo ważny. Mowa bowiem o przedsięwzięciu uruchomionym i prowadzonym przez legionowych weteranów ${ }^{25}$, które od 1926 roku pozostawało bardzo mocno związane z obozem rządzącym, od 1935 roku zaś będącym współwłasnością ludzi wprost z niego się wywodzących, pod nadzorem szarej eminencji "grupy pułkowników”, Bogusława Miedzińskiego. Warto przy tym dodać, że po 1935 roku ani nie doszło do zmian wśród osób bezpośrednio zarządzających pismami koncernu, ani też kształt dzienników nie uległ jakiejś poważniejszej korekcie ${ }^{26}$. Pełny obraz działalności pisma musiałby zatem uwzględniać wyjątkową bliskość między Prasą Polską, zwłaszcza należącymi do niej dziennikami, a Marszałkiem Piłsudskim, który zezwalał na publikowanie tam zdjęć swoich i swojej rodziny o znacznie bardziej prywatnym charakterze niż w innych gazetach, a także, wyjątkowo co prawda, na jego łamach publikował ${ }^{27}$. Jest to tylko jedno ze świadectw populistycznego charakteru pism; populistycznego w głębszym sensie niż zazwyczaj przypisuje się to grającej na ludzkich emocjach prasie popularnej. Byłby to bowiem rodzaj okna wystawowego rządzących, czy, w większym stopniu nawet, narzędzie kreowania wrażenia więzi między „władzą" a „ludem”. Część akcji społecznych pisma wyraźnie nosi ślad gestu „wyjścia władzy do ludu”, aby pytać o jego potrzeby i je spełniać. Inna sprawa, że działania te dotyczyły często dość szczególnych grup, np. rodzin zawodowych podoficerów, którym miano zapewnić stosowną opiekę społeczną. Pojawić by się musiało pytanie o wykorzystanie legendotwórczych mechanizmów w kontekście politycznym; wydaje się, że tworzenie legendy Marszałka czy budowanie wizerunku BBWR (zwłaszcza w okresie wyborczym) zdradzało takie strategie w znacznie większym stopniu, niż działania omówione powyżej. Wypadałoby wreszcie postawić kwestię całościowej strategii koncernu w okresie pomajowym. Działalność Prasy Polskiej jest bowiem bliska czemuś, co można byłoby nazwać projektem prasy popularnej dla nowoczesnego Polaka. Poza kształtowaniem warszawskiego vox populi przez dzienniki, koncern wydawał także "Przegląd Sportowy”, „Kino" i satyrycznego "Cyrulika Warszawskiego". Warto się zatem zastanowić, czy nie mamy tu do czynienia z dość

25 Nota bene Stefan Wiechecki w momencie, gdy został zatrudniony przez koncern, nie miał większego doświadczenia dziennikarskiego, mógł natomiast pochwalić się przeszłością w Legionach, gdzie dosłużył się stopnia porucznika.

26 Wydaje się, że akcja przejęcia kontroli nad koncernem przez obóz rządzący mogła mieć związek z rosnącymi konfliktami w łonie sanacji podczas choroby i po śmierci Marszałka Piłsudskiego, w gruncie rzeczy nie wpłynęła ona jednak na kształt i wymowę wydawanych pism - co zresztą wydaje się bardzo znaczące.

27 Numer z 19 marca 1930 r. 
zideologizowanym (a przynajmniej stanowiącym próbę jakiegoś rodzaju inżynierii społecznej) projektem modelowania opinii pod pozorem braku ideologii. To już jednak okazja do rozpoznania problemu z zupełnie innej strony, niż niniejszy tekst zakładał.

\section{The "Czerwoniak" Phenomenon and the Mid-War Warsaw Legend}

\section{Summary}

The text shows how the popular dailies of the 1920s and 30s, the so called "red press" helped to create the legend of the mid-war Warsaw. It investigates the editorial strategies and their role in disseminating urban legends. Additionally, significant attention has been devoted to the city topography in "Express Poranny".

Keywords: urban legend, popular dailies, creating legend, mid-war Warsaw 